\title{
The impact of anthropogenic pollution on limnological characteristics of a subtropical highland reservoir "Lago de Guadalupe", Mexico
}

\author{
A. Sepulveda-Jauregui( ${ }^{(1)}$, J. Hoyos-Santillan ${ }^{(1),(2)}$, F.J. Gutierrez-Mendieta(3), \\ R. Torres-Alvarado ${ }^{(3)}$, L. Dendooven ${ }^{(4)}$, F. Thalasso ${ }^{(1), \star}$
}

Received January 14, 2013

Revised May 28, 2013

Accepted June 6, 2013

\begin{abstract}
Key-words: hypereutrophic, monomictic, morphometry, pollution, subtropical

"Lago de Guadalupe" is an important freshwater ecosystem located in the northern part of the metropolitan area surrounding Mexico City, under high demographic pressure. It receives approximately $15 \mathrm{hm}^{3} \cdot \mathrm{y}^{-1}$ of untreated municipal wastewater from the surrounding municipalities. In order to develop a comparative assessment of the pollution effect over the limnological characteristics of Lago de Guadalupe, this lake was characterised from February 2006 to July 2009, and the results were compared with those obtained from a non-polluted lake "Lago el Llano" located in the same drainage area. Lago de Guadalupe was hypereutrophic with anoxic conditions throughout most of the water column. In contrast, Lago el Llano was mesotrophic with high dissolved oxygen concentrations throughout the entire water column with a clinograde profile. Both reservoirs had a monomictic mixing regime. The longitudinal zonation of physicochemical and biological variables were investigated in order to better understand the processes controlling the water quality across the reservoir during its residence time. This study shows the impact of anthropogenic pollution on the limnological characteristics of a subtropical reservoir and confirms that under adequate management schemes, namely avoiding pollution and wastewater discharges, subtropical reservoirs can be prevented from developing eutrophic conditions.
\end{abstract}

\section{ABSTRACT}

\section{RÉSUMÉ}

Impact de la pollution anthropique sur les caractéristiques limnologiques d'un réservoir subtropical de montagne, le «Lago de Guadalupe », Mexique

Mots-clés : hypereutrophie, monomictique, morphometrie,
Le Lago de Guadalupe est un important écosystème aquatique situé dans la partie nord de la zone urbaine de la ville de Mexico, subissant une forte pression démographique. Ce lac artificiel d'environ 60 hectomètres cubes, reçoit environ 15 hectomètres cubes par an d'eaux usées provenant des agglomérations environnantes. Afin d'évaluer l'effet de la pollution sur les caractéristiques limnologiques du Lago de Guadalupe, ce lac a été caractérisé de février 2006 à juillet 2009. Les résultats

(1) Department of Biotechnology and Bioengineering, Cinvestav Av. IPN 2508, Col. San Pedro Zacatenco, MX 07360, Mexico City, Mexico

(2) School of Biosciences, Division of Agricultural and Environmental Science, University of Nottingham, Sutton Bonington Campus Loughborough,UK LE12 5RD, Nottingham, UK

(3) Department of Hydrobiology, Autonomous Metropolitan University, UAM-I, Av. San Rafael Atlixco 186, Col. Vicentina, MX 09340, Mexico City, Mexico

(4) Abacus, Cinvestav Av. IPN 2508, Col. San Pedro Zacatenco, MX 07360, Mexico City, Mexico

* Corresponding author: thalasso@cinvestav.mx 
pollution, subtropical ont été comparés avec ceux observés dans un autre lac artificiel, non pollué : Lago el Llano, situé dans le même bassin versant et soumis au même climat que le Lago de Guadalupe. Les résultats obtenus montrent que le Lago de Guadalupe est hypereutrophe comme en témoignent les conditions anaérobies rencontrées dans la majeure partie de la colonne d'eau. En revanche, le Lago el Llano est mésotrophe avec présence d'oxygène dans toute la colonne d'eau. Les deux lacs présentent un régime monomictique. La zonation longitudinale des variables physico-chimiques et biologiques a été étudiée afin de mieux comprendre les processus qui contrôlent la qualité de l'eau. Cette étude montre l'impact de la pollution anthropogénique sur les caractéristiques limnologiques de lacs subtropicaux et confirme l'importance de réduire les apports anthropogéniques de nutriments pour ralentir le phénomène d'eutrophisation.

\section{INTRODUCTION}

Approximately 45000 water reservoirs exist worldwide, most of them constructed for irrigation purposes (Cosgrove and Rijsberman, 2000). Around the world, between 30 and $40 \%$ of the 268 million ha of irrigated land are dependent on reservoirs for their water supply. There are more than 4000 reservoirs in Mexico, 667 of them are classified as large dams (Waltz et al., 2007). Mexico's 52 largest lakes hold 60\% of the country's total reservoir capacity (CONAGUA, 2007). Approximately $21 \%$ of the total population of Mexico (i.e. 112 million people) is concentrated in the Mexico City metropolitan area, which accounts for less than $0.5 \%$ of the total national territory area of $1964000 \mathrm{~km}^{2}$ (INEGI, 2011). The denselypopulated central region of the country is particularly vulnerable to limited water supplies. Approximately 593 wastewater treatment plants operate in Mexico, treating only $26 \%$ of the total wastewater flow produced nationwide (CONAGUA, 2007). The remaining 74\% usually end up in aquatic ecosystems, causing cultural eutrophication. Consequently, most of the Mexican reservoirs located within or close to urban areas are heavily polluted with dire consequences for the aquatic ecosystems biodiversity as well as potential risks for public health (Welch and Jacoby, 2004). This is generating a growing concern as the volume of wastewater produced is increasing due to further urbanization and economic development. Improvement of wastewater management appears to be essential for future human and environmental welfare. The latter is of foremost importance in Mexico, where the water bodies are subject to tropical or subtropical climates and thus are naturally more prone to eutrophication than temperate or boreal climates water bodies (Lewis Jr, 1996).

The vast Mexican plateau with an extension of $600000 \mathrm{~km}^{2}$ and an altitude between 1000 to $2700 \mathrm{~m}$ above mean sea level (a.s.l.) is located between $18^{\circ} \mathrm{N}$ and $28^{\circ} \mathrm{N}$ (northern latitudes). It has a subtropical climate and even though few studies have been conducted in this region, the impact of water pollution on subtropical lakes ecology is of major concern. In this study, a subtropical reservoir, "Lago de Guadalupe" (LG) was used as model to address the impact of anthropogenic pollution on limnological characteristics of reservoirs. LG was selected for being polluted by important wastewater discharges and to test the following hypothesis: (i) $L G$ developed a longitudinal zonation of water quality and trophic state across its major axis due to urban wastewater discharges; and (ii) the eutrophic state of LG is not a result of the regional climatic conditions. The seasonal and spatial variations of physical, chemical and biological variables were determined in LG and compared to those in a nearby non-polluted lake "Lago el Llano" (LL). LL is located in the same drainage basin and at the same altitude as LG, so it is subject to the same macroclimatic conditions. This study provided the opportunity to evaluate the consequences of poor reservoir management reflected by the negative impact of urban wastewater discharges over subtropical reservoir ecosystems. 

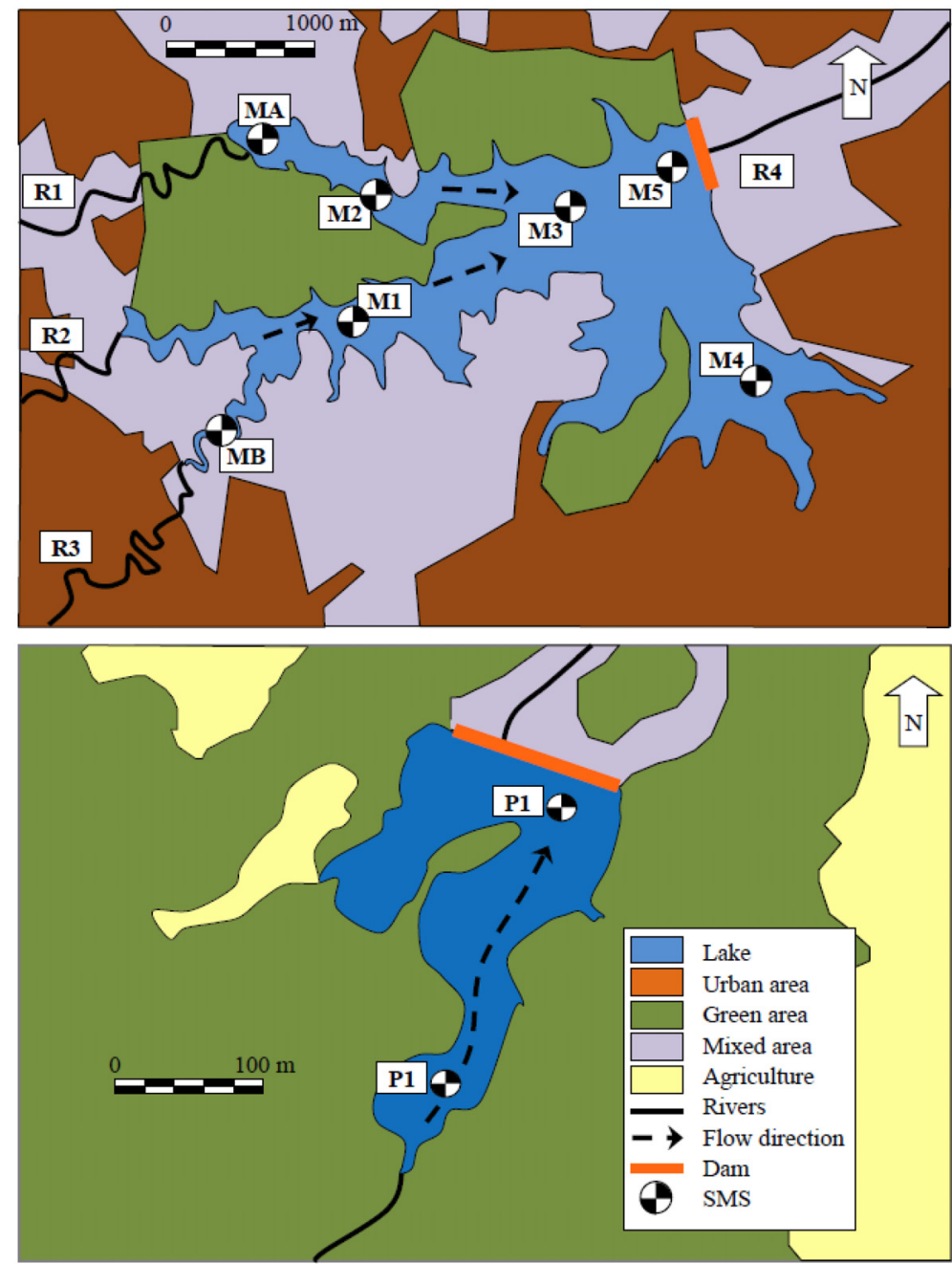

\section{Figure 1}

Sampling and monitoring stations at Lakes "Lago de Guadalupe" (Top) and "Lago el Llano" (Bottom). Lago de Guadalupe: 19.630 (Latitude), -99.260 (Longitude); Lago el Llano: 19.658 (Latitude), -99.507 (Longitude). Rivers: Río San Pedro (R1), Río Cuautitlán (Arroyo Grande and Arroyo Chico) (R2), Río Xinté (R3) and Río Cuautitlán (R4).

\section{STUDY SITES}

LG is a tributary reservoir constructed in 1943 as an irrigation and flood control system. General properties of LG are listed in Table I. According to Hutchinson's classification criteria, LG is a "73" type artificial lake (Hutchinson, 1957), while according to the International Commission on Large Dams (ICOLD) criteria, LG is considered a large dam (Waltz et al., 2007). LG is located within Mexico City metropolitan area at $2240 \mathrm{~m}$ a.s.l. and $25 \mathrm{~km}$ northwest of the centre of Mexico City (19.6310 N, 99.2567 W). According to the longitudinal pattern model of Thornton et al. (1990), LG has three distinct constitutive zones, i.e. fluvial, transitional and lacustrine, which are morphologically distinct from each other in depth and proximity to the dam. The reservoir has an irregular shoreline and its major axis goes from the southwest to the northeast following the water flow from the fluvial zone towards the lacustrine zone where the dam is located (Figure 1). The climate in the area is temperate sub-humid with most of the precipitation in summer (García, 1973). The lake is habitat for more than 150 bird species both endemic and migratory, such as Pelecanus erythrorhynchos, Anas platyrhyncho, Anas diazi and Aythya affinis. In the western region (fluvial zone), the reservoir receives untreated urban wastewater discharges from three tributary rivers (i.e. Cuautitlán, Xinté and San Pedro). 
Table I

Morphometric parameters of "Lago de Guadalupe" (LG) and "Lago el Llano" (LL) reservoirs.

\begin{tabular}{|c|c|c|}
\hline Parameter & LG & LL \\
\hline Altitude (m) & 2320 & 2840 \\
\hline Direction of major axis & SW-NE & SSW-NNE \\
\hline Maximum depth, $z_{\max }(\mathrm{m})$ & 17 & 14 \\
\hline Maximum length, I (m) & 3,858 & 447 \\
\hline Maximum effective length, If $(\mathrm{m})$ & 3,858 & 447 \\
\hline Maximum width, $b(\mathrm{~m})$ & 2,522 & 209 \\
\hline Shoreline length, $L$ (m) & 31,574 & 1.660 \\
\hline Area, $A$ (ha) & 450 & 5.69 \\
\hline Volume, $V\left(\mathrm{hm}^{3}\right)$ & 60 & 0.54 \\
\hline Mean depth, $z_{m}(\mathrm{~m})$ & 13.3 & 9.49 \\
\hline Relative depth, $z_{\mathrm{r}}(\%)$ & 0.71 & 5.20 \\
\hline Shoreline development, $D_{\mathrm{L}}$ & 4.19 & 1.96 \\
\hline Volume development, $D_{v}$ & 2.35 & 2.03 \\
\hline Dynamic ratio, $D_{\mathrm{R}}$ & 0.581 & 0.077 \\
\hline
\end{tabular}

The estimated total discharge is $15 \mathrm{hm}^{3} / \mathrm{y}$ and equals $25 \%$ of the LG total volume (2 years of residence time) (Gutierrez-Díaz, 2006, Personal communication. Environmental Department Director, Cuautitlan Izcalli, Mexico). A nearby unpolluted study site was selected and characterized for comparison with LG. The selected site was LL (19.6577 N, $99.5069 \mathrm{~W})$, which is a 6 ha fetch reservoir located within the same drainage basin ( $26 \mathrm{~km}$ west of LG). LL is located in a protected area and receives water from an unpolluted tributary river and springs. General properties of LL are listed in Table I.

\section{MATERIALS AND METHODS}

\section{> BATHYMETRY AND MORPHOMETRY}

The surface area $(A)$ was obtained through image analysis of aerial photographs. Depth measurements were taken with a Digital Depth Sounder (Hondex, Mexico). Volume (V) was estimated from depth and area measurements. Morphometric parameters, i.e. average depth $\left(z_{m}\right)$, maximum depth $\left(z_{\max }\right)$, relative depth $\left(z_{r}\right)$, maximum length $(\eta)$, maximum effective length $\left(l_{\mathrm{f}}\right)$, maximum width $(\mathrm{b})$, shoreline length $(\mathrm{L})$, shoreline development $\left(D_{\mathrm{L}}\right)$, development of volume $\left(D_{\mathrm{V}}\right)$ and dynamic ratio $\left(D_{\mathrm{R}}\right)$, were determined as stipulated in literature (Hakanson, 1981; Hutchinson, 1957; Lindstrom and Hakanson, 1999; Wetzel and Likens, 2000). The parameters $z_{\mathrm{m}}, z_{\mathrm{r}}, D_{\mathrm{L}}, D_{\mathrm{V}}$ and $D_{\mathrm{R}}$ were calculated using equations (1) to (5):

$$
\begin{aligned}
& z_{\mathrm{m}}=\frac{V}{A} \\
& z_{\mathrm{r}}=50 z_{\max } \sqrt{\frac{\pi}{A}} \\
& D_{\mathrm{L}}=\frac{L}{2 \sqrt{\pi A}} \\
& D_{\mathrm{V}}=\frac{3 z_{\mathrm{m}}}{z_{\max }} \\
& D_{\mathrm{R}}=\sqrt{\frac{A \times 1 \times 10^{-6}}{z_{\mathrm{m}}}}
\end{aligned}
$$




\section{> SAMPLING AND MONITORING STATIONS}

The physicochemical characteristics at LG were determined at least three times per year from February 2006 to July 2009 (Table II). Seven sampling and monitoring stations (SMS) were established and distributed across the fluvial, transitional and lacustrine zones to determine spatial variations across the reservoir (Figure 1). The SMS located at the fluvial zone were named $M A$ and $M B$, while those located at the transitional zone were named $M 1$ and $M 2$, and those at the lacustrine zone were named M3, M4 and M5. LL was characterized two times in July and December 2009. Due to the smaller size of LL, only two SMS were set up, one located at the fluvial zone and another at the lacustrine zone (Figure 1).

\section{> PHYSICAL, CHEMICAL AND BIOLOGICAL VARIABLES}

Measurements of in situ parameters included: temperature, $\mathrm{pH}$, dissolved oxygen (DO), oxidation reduction potential (ORP), conductivity and total suspended solids (TSS). The aforementioned parameters were measured at different depths in each SMS using a calibrated multiparametric probe (556 MPS, YSI, USA). Secchi disk depth (SDD) was measured with a $20 \mathrm{~cm}$ Secchi disk. Water samples for ex situ analysis were collected using a $2.2 \mathrm{~L}$ horizontal Van Dorn bottle (WILDCO, USA) at the same depths as in situ measurements. Water samples were transferred to polypropylene containers and handled according to ASTM protocols. The $\mathrm{NO}_{2}^{-}, \mathrm{NO}_{3}^{-}, \mathrm{NH}_{4}^{+}, \mathrm{SO}_{4}^{2-}$, soluble reactive phosphorus (SRP), chemical oxygen demand (COD), biochemical oxygen demand $\left(\mathrm{BOD}_{5}\right)$, chlorophyll a $(\mathrm{Chl}-\mathrm{a})$, total and faecal coliforms, and faecal streptococci were determined according to standard methods protocols (APHA, 1999), whereas total carbon (TC), inorganic carbon (IC), total organic carbon (TOC) and total nitrogen (TN) were measured with a total carbon and nitrogen analyser (Shimadzu Vcsn equipped with a TN1 module). Additionally, sediments samples were collected using a Petersen grab type dredge (Zhang, 2007). Sediments were analysed for TOC, $\mathrm{SO}_{4}^{2-}$, total phosphorus (TP), Kjeldahl nitrogen, dry weight and loss on ignition.

\section{$>$ TROPHIC STATE AND WATER QUALITY INDEXES}

Trophic state indexes (TSI) were used to estimate cultural eutrophication (Carlson, 1977). Secchi depth (TSI-SD), chlorophyll a (TSI-Chl-a) and total phosphorus (TSI-P) were used to calculate the trophic state indexes. Additionally, a Water Quality Index (WQI) was calculated with a weighted multiplicative function (Eq. (6)) of several parameter quality indexes (QI); where Wi is the weight of each quality index. Seven parameters were considered; faecal coliforms, $\mathrm{pH}$, $\mathrm{DBO}_{5}$, nitrates, SRP, TSS and DO. Qi were obtained from the National Sanitary Foundation (www.water-research.net/watrqualindex) and Wi values were modified from Fernandez and Solano (2005); i.e. 0.176, 0.146, 0.126, 0.126, $0.126,0.105$ and 0.195 for faecal coliforms, $\mathrm{pH}, \mathrm{DBO}_{5}$, nitrates, SRP, TSS and DO, respectively.

$$
W Q I=\prod_{i=1}^{n} Q_{i}^{W_{i}}
$$

\section{STATISTICAL ANALYSIS}

Significant differences were determined using the Tukey-Kramer's multiple comparison tests performed after analyses of variance $(P<0.05)$. In addition, Pearson product-moment correlation coefficients were estimated to explore the relationship between the longitudinal zonation and different parameters used as water quality indicators. All statistical analyses were done with $R$ language ( $R$ core team, 2012). 


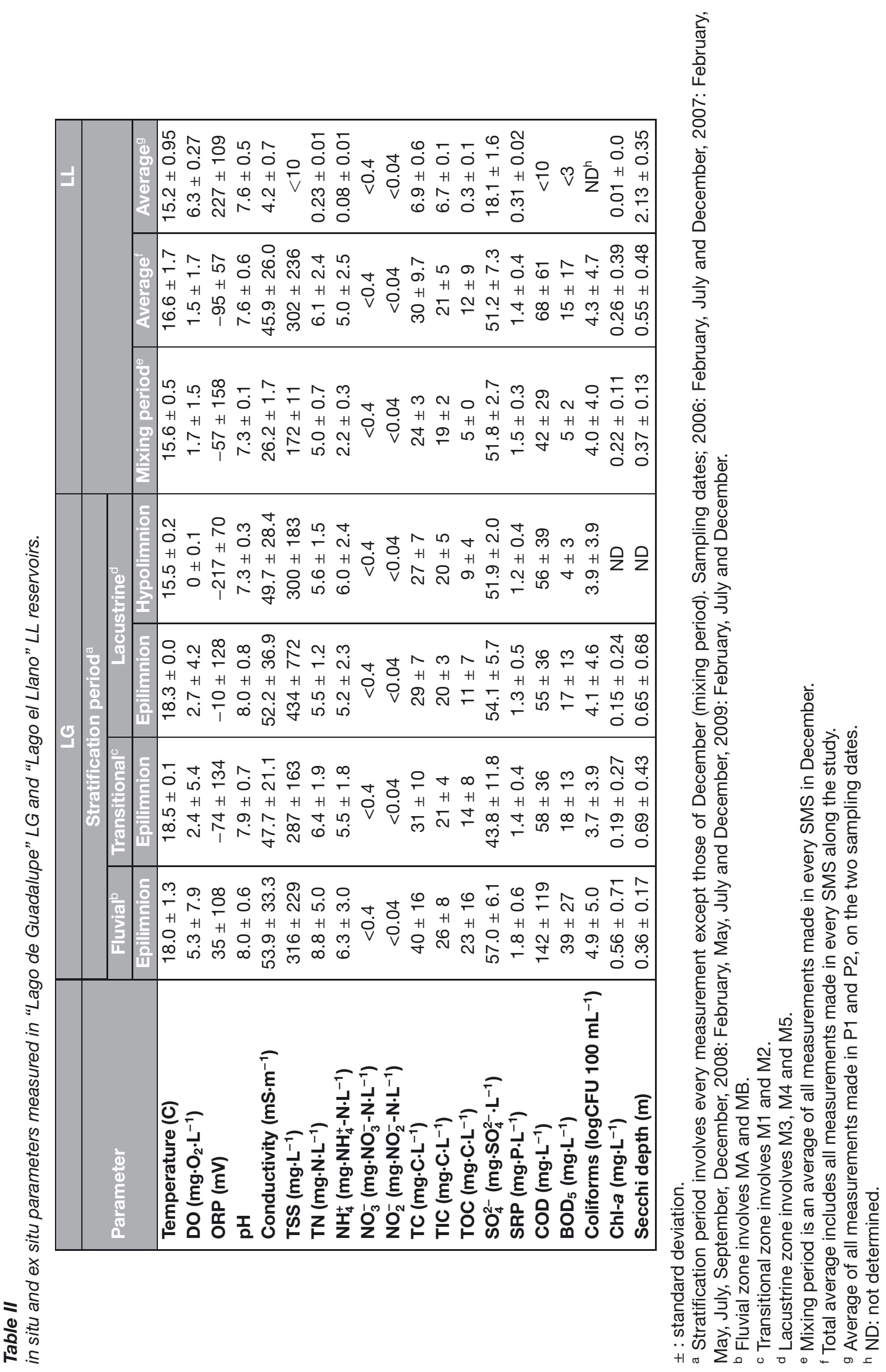



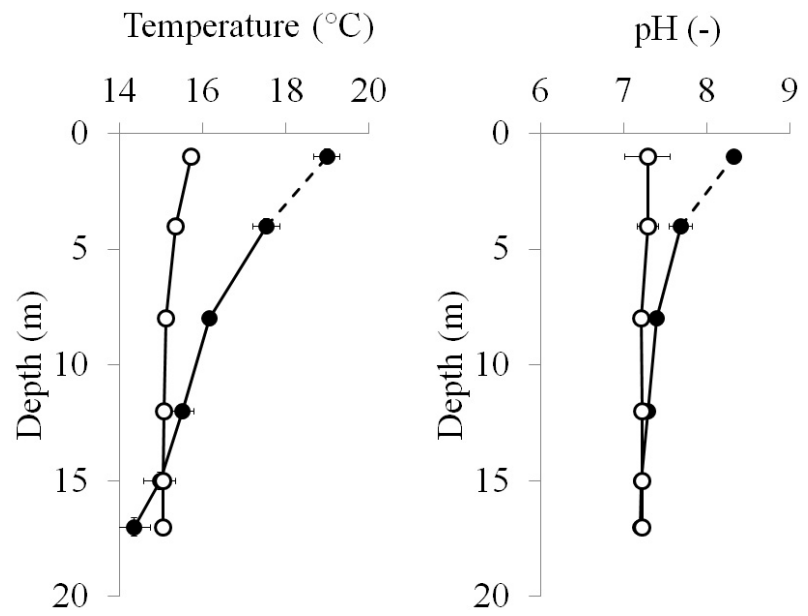

Figure 2

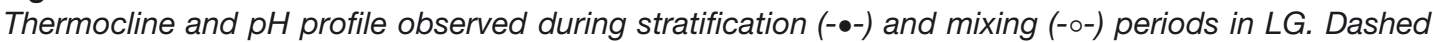
lines indicate thermocline and $\mathrm{pH}$-cline respectively.

\section{RESULTS}

\section{> LG CHARACTERIZATION}

\section{Bathymetry and morphometry}

The results of the morphometric analysis of LG are summarized in Table I. The fluvial, transitional and lacustrine areas of LG corresponded to approximately 10,25 and $65 \%$ of the total surface area, respectively. The fluvial zone, which received the wastewater discharge, was 1 to $4 \mathrm{~m}$ deep. The transitional zone was between 5 and $9 \mathrm{~m}$ deep, with a lower depth near the shore, while the lacustrine zone was between 10 and $17 \mathrm{~m}$. LL was characterised by a small fluvial area and it was not possible to make a clear distinction between the transitional and lacustrine zones. Therefore, only the LL fluvial and lacustrine zones were considered. The fluvial and lacustrine areas of LL corresponded to approximately 15 and $85 \%$ of the total lake surface. The fluvial zone, which received unpolluted tributary river and springs, was between 1 and $6 \mathrm{~m}$ deep, while the lacustrine zone was between 9 and $14 \mathrm{~m}$.

\section{LG thermal stratification, mixing regime, $\mathrm{pH}$ and oxygen distribution}

Temperature, oxygen and ORP profiles were used to differentiate the epilimnion (0 to $4 \mathrm{~m}$ deep) and the hypolimnion (8 to $17 \mathrm{~m}$ deep). The LG water column remained thermally stratified from spring to autumn, maintaining a 2 to $5{ }^{\circ} \mathrm{C}$ temperature difference between surface and bottom layers. During this period, a thermocline was observed between 3 and $4 \mathrm{~m}$ depth (Figure 2). During winter, however, the temperature difference between the surface and bottom layers decreased to $0.5{ }^{\circ} \mathrm{C}$, reaching homothermy (Figure 2). The LG average yearly temperature was $17.9{ }^{\circ} \mathrm{C}$ for the epilimnion and $15.4{ }^{\circ} \mathrm{C}$ for the hypolimnion. The epilimnion temperature was not significantly different over time within either the fluvial or transitional zones $(P<0.05)$. However, temperatures in the lacustrine zone epilimnion were significantly different over time $(P<0.05)$. The maximum temperature of $20.5{ }^{\circ} \mathrm{C}$ in the epilimnion and $17.8^{\circ} \mathrm{C}$ in the hypolimnion were measured in May, while a minimum of $14.4^{\circ} \mathrm{C}$ in the epilimnion and $13.5^{\circ} \mathrm{C}$ in the hypolimnion were measured in February.

The DO in the LG water column decreased with depth describing a clinograde oxygen curve (Figure 3). During the entire study period, the hypolimnion showed anoxic conditions (DO concentration $\approx 0 \mathrm{mg} \cdot \mathrm{O}_{2} \cdot \mathrm{L}^{-1}, \mathrm{ORP}<-200 \mathrm{mV}$ ), which is indicative of an eutrophic state. The epilimnion DO average during the studied period was $1.5 \pm 1.7 \mathrm{mg} \cdot \mathrm{O}_{2} \cdot \mathrm{L}^{-1}$. In the epilimnion of 

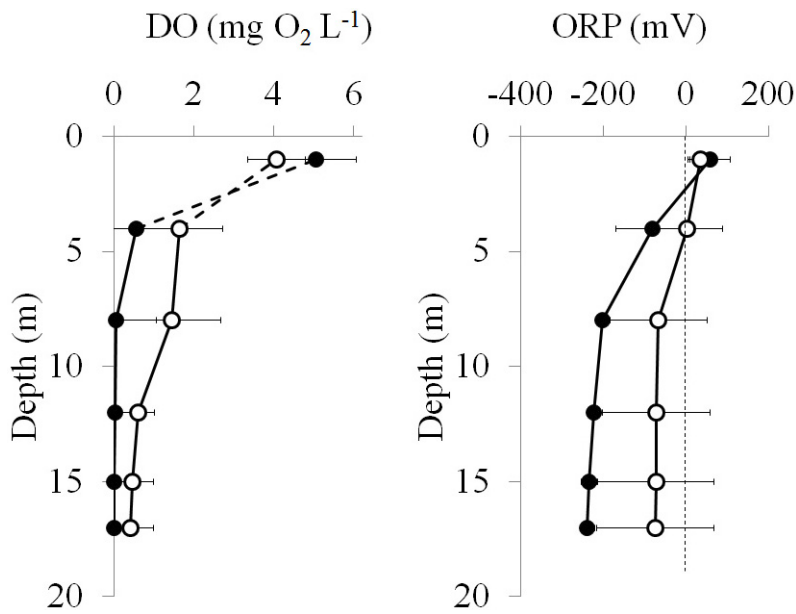

Figure 3

Oxycline and ORP profile observed during stratification (-•-) and mixing (-०-) periods in LG. Dashed lines indicate oxycline.

the fluvial zone, with the exception of an algal blooming that occurred in February 2007, DO concentrations remained below $1.3 \mathrm{mg} \cdot \mathrm{L}^{-1}$ (mean $0.4 \mathrm{mg} \cdot \mathrm{L}^{-1}$ ). The ORP data were consistent with DO concentrations (i.e. low ORP values corresponded to low DO concentrations). Even though oxygen concentrations were generally low or negligible, the hypolimnion contained oxygen concentrations averaging $0.76 \pm 0.16 \mathrm{mg} \cdot \mathrm{O}_{2} \cdot \mathrm{L}^{-1}$ in the lacustrine zone during winter when mixing of the water column was observed. Due to algal blooms $\left(\mathrm{Chl}-\mathrm{a}=0.8 \mathrm{mg} \cdot \mathrm{L}^{-1}\right)$ in the spring, DO concentrations were above saturation (up to $18 \mathrm{mg} \cdot \mathrm{O}_{2} \cdot \mathrm{L}^{-1}$ ) in the fluvial zone. The maximum $\mathrm{pH}$ (9.31) was recorded in the fluvial zone during the algal bloom. The minimum $\mathrm{pH}$ recorded (6.90) was in the hypolimnion of the lacustrine zone during stratification. The $\mathrm{pH}$ decreased throughout the water column in the lacustrine zone during stratification (Figure 2).

\section{$>$ WATER ANALYSES}

Nitrate and nitrite concentrations were constantly below detection limits $\left(0.4 \mathrm{mg} \cdot \mathrm{NO}_{3}^{-} \mathrm{N} \cdot \mathrm{L}^{-1}\right.$ and $0.04 \mathrm{mg} \cdot \mathrm{NO}_{2}^{-}-\mathrm{N} \cdot \mathrm{L}^{-1}$; Table II). Sulphate was found in $\mathrm{LG}$ with an average concentration of $51.2 \pm 7.3 \mathrm{mg} \cdot \mathrm{SO}_{4}^{2-} \cdot \mathrm{L}^{-1}$ (Table II). The average ammonium concentration was $5.3 \pm 2.7 \mathrm{mg} \cdot \mathrm{NH}_{4}^{+}-$ $\mathrm{N} \cdot \mathrm{L}^{-1}$. A maximum of $12.73 \mathrm{mg} \cdot \mathrm{NH}_{4}^{+}-\mathrm{N} \cdot \mathrm{L}^{-1}$ was detected in the fluvial zone during the stratification period, and a minimum of $1.55 \mathrm{mg} \cdot \mathrm{NH}_{4}^{+}-\mathrm{N} \cdot \mathrm{L}^{-1}$ was detected in the epilimnion of the lacustrine zone during the mixing period.

LG received constant carbon, nitrogen and phosphorus inputs in the fluvial zone. Both TOC and TN were high and showed a longitudinal zonation (Figure 4). The highest SRP (2.59 mg.P. $\left.\mathrm{L}^{-1}\right)$ was found in the fluvial zone, while the lowest $\left(0.58 \mathrm{mg} \cdot \mathrm{P} \cdot \mathrm{L}^{-1}\right)$ was in the lacustrine zone. The highest TN $\left(17.79 \mathrm{mg} \cdot \mathrm{N} \cdot \mathrm{L}^{-1}\right)$ was also found in the fluvial zone and the lowest $\left(0.33 \mathrm{mg} \cdot \mathrm{N} \cdot \mathrm{L}^{-1}\right)$ in the lacustrine zone. The ratio of mineral nitrogen (DIN $=$ nitrate + nitrite + ammonium) over SRP reached a maximum of 7.00 and an average of $3.35 \pm 1.13$, but was not significantly different over time.

As previously mentioned, LG received urban wastewater discharges containing high quantities of organic matter. The organic matter content was measured indirectly through TOC, $\mathrm{COD}$ and $\mathrm{BOD}_{5}$. A clear longitudinal zonation of these three parameters was observed (Figures 4, 5). Maximum TOC, $\mathrm{COD}$ and $\mathrm{BOD}_{5}$ values were all found in the fluvial zone with values of $46 \mathrm{mg} \cdot \mathrm{C} \cdot \mathrm{L}^{-1}, 416$ and $70 \mathrm{mg} \cdot \mathrm{L}^{-1}$, respectively. Minimum TOC, COD and $\mathrm{BOD}_{5}$ values were all found in the lacustrine zone with values of $3 \mathrm{mg} \cdot \mathrm{C} \cdot \mathrm{L}^{-1}, 21$ and $0.9 \mathrm{mg} \cdot \mathrm{L}^{-1}$, respectively. Chl-a and SDD were used as primary productivity indicators. Chl-a was also clearly subject to a longitudinal zonation (Figure 5). The minimum Chl-a $\left(0.003 \mathrm{mg} \cdot \mathrm{L}^{-1}\right)$ values were measured in the lacustrine zone during the stratification period and the corresponding 


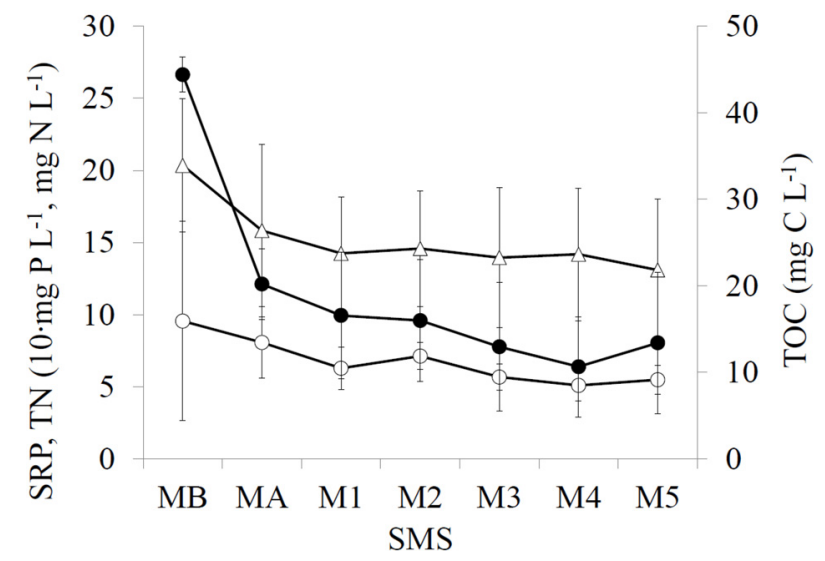

\section{Figure 4}

Longitudinal TN (-o-), TOC (-๑-) and SRP (- - -) profiles in LG. SRP values are multiplied by 10 for clearer representation.

\section{Figure 5}

Longitudinal Chlorophyll a (-๑-), $C O D(-\Delta-)$ and $B O D_{5}(-\circ-)$ profiles in $L G$.

SDD was $2.2 \mathrm{~m}$, which was the maximum measured. The lowest SDD $(0.15 \mathrm{~m})$ was measured where the highest $\mathrm{Chl}-\mathrm{a}\left(0.8 \mathrm{mg} \cdot \mathrm{L}^{-1}\right)$ was found.

Differences of microbiological indicators (i.e. total and faecal coliforms and faecal streptococci concentrations) were observed between fluvial, transitional and lacustrine zones. Higher concentrations of microbiological indicators were found in the fluvial zone during the stratification period. The average concentrations of total coliform bacteria, faecal coliform bacteria and faecal streptococci were $5.29 \pm 1.55,4.05 \pm 1.01$ and $2.13 \pm 0.20 \log$ CFU $100 \mathrm{~mL}^{-1}$, respectively.

\section{> SEDIMENT ANALYSIS}

No significant differences were found in TOC, Kjeldahl nitrogen, total phosphorus and sulphate concentrations in LG sediments throughout the monitoring period. The average TOC content in sediment samples of all SMS was $40 \pm 18 \mathrm{~g} \cdot \mathrm{kg}^{-1}$.dry.weight. The highest TOC value was found in the lacustrine zone $\left(97 \mathrm{~g} \cdot \mathrm{kg}^{-1} \cdot \mathrm{dry} \cdot\right.$ weight), while the minimum was found in the fluvial zone (21.34 g. $\mathrm{kg}^{-1} \cdot \mathrm{dry}$.weight). The average Kjeldahl nitrogen concentration measured $3.64 \pm 1.20 \mathrm{~g} \cdot \mathrm{N} \cdot \mathrm{kg}^{-1} \cdot \mathrm{dry} \cdot$ weight, total phosphorus concentration measured $1.40 \pm 0.30 \mathrm{~g} \cdot \mathrm{P} \cdot \mathrm{kg}^{-1} \cdot \mathrm{dry} \cdot$ weight and sulphate concentration measured $0.94 \pm$ $0.28 \mathrm{~g} \cdot \mathrm{SO}_{4}^{2-} \cdot \mathrm{kg}^{-1} \cdot \mathrm{dry} \cdot$ weight. 


\section{> LL CHARACTERIZATION}

LL had a maximum depth of $14 \mathrm{~m}$ and shoreline development of 1.96 , similar to that of LG (Table I). Data collected on temperature, thermal stratification and mixing regime allowed us to classify LL as a warm monomictic reservoir. Since LL was not receiving wastewater discharges, significant differences were found between the two lakes. Table II shows the average parameters determined in LL. DO slightly decreased with depth during the stratification period, however the water column was oxic, with an average DO concentration of $6.1 \pm 0.8 \mathrm{mg} \cdot \mathrm{O}_{2} \cdot \mathrm{L}^{-1}$ in the epilimnion and $4.7 \pm 1.1 \mathrm{mg} \cdot \mathrm{O}_{2} \cdot \mathrm{L}^{-1}$ in the hypolimnion. SDDs were significantly higher than those observed in $L G(2.4 \pm 0.4 \mathrm{~m})$ and water analyses showed average TOC and TN values of $3.36 \pm 0.16 \mathrm{mg} \cdot \mathrm{C} \cdot \mathrm{L}^{-1}$ and $0.41 \pm 0.07 \mathrm{mg} \cdot \mathrm{N} \cdot \mathrm{L}^{-1}$, respectively. COD, nitrate, nitrite, TN and phosphorus were below detection limits.

\section{DISCUSSION}

\section{> LG BATHYMETRY AND MORPHOMETRY}

LG has a highly irregular shoreline, reflected by its $D_{\mathrm{L}}$ of 4.19 . The measured $z_{\mathrm{r}}(0.7 \%)$ was less than $4 \%$, indicating that the reservoir is shallow with a relatively large surface area (Hutchinson, 1957). This suggests that $L G$ is mixed by wind in its shallower parts (i.e. fluvial and transitional zone), while the lacustrine zone is deep enough to remain stratified throughout most of the year (Hutchinson, 1957; Wetzel, 2001). A $D_{\mathrm{R}}$ of 0.16 indicates that LG sediments in shallower areas are re-suspended by wind-wave effects. The $D_{\mathrm{v}} / 3$ of 0.78 suggests that $78 \%$ of the sediments subjected to re-suspension are transported to deep waters, while the remaining $22 \%$ are transported to surface waters (Castro et al., 2003; Hakanson, 1981). The results presented here confirm the stratification of the lacustrine zone, as well as a significant longitudinal zonation. This longitudinal zonation was undoubtedly the result of biological activity and LG's morphology since lake morphology partly determines its metabolism, as it exerts a major influence on physical, chemical and biological parameters (Wetzel, 2001).

\section{> LG THERMAL STRATIFICATION, MIXING REGIME AND OXYGEN DISTRIBUTION}

LG receives a relatively high and regular solar irradiance $\left(\approx 460 \mathrm{cal} \cdot \mathrm{cm}^{-2}\right.$. day $\left.{ }^{-1}\right)$ due to its latitude (Lewis Jr, 1987). Consequently, the epilimnion temperature is expected to be higher than that of the hypolimnion, resulting in thermal stratification in both the transitional and lacustrine zones during most of the year. This was confirmed by temperature differences of up to $5{ }^{\circ} \mathrm{C}$ between the epilimnion and hypolimnion. However, during winter, the thermal stratification disappeared. These changes are typical for warm monomictic water bodies as reported by Hutchinson and Loffler (1956) and by Tundisi (1994), but differ from the warm polymictic thermal cycle reported by Lewis Jr (1983) for other lakes at LG's latitude with similar depths. Nevertheless, the warm monomictic cycle of $L G$ is consistent with the thermal cycle described by Merino-lbarra et al. (2007) for Valle de Bravo reservoir, located at 1780 $\mathrm{m}$ a.s.l., $106 \mathrm{~km}$ SW from LG. Similar thermal and oxygen profiles in the water column were observed by Vazquez et al. (2004) in a tropical lake with an average water temperature higher than LG $\left(21\right.$ to $\left.26^{\circ} \mathrm{C}\right)$.

In the epilimnion of the LG fluvial zone, DO occasionally reached $18 \mathrm{mg} \cdot \mathrm{O}_{2} \cdot \mathrm{L}^{-1}$ (i.e. above saturation) when the Chl-a concentration reached $0.8 \mathrm{mg} \cdot \mathrm{L}^{-1}$. DO at oversaturation concentrations are often reported in tropical-subtropical hypereutrophic systems because of enhanced primary productivity. This has been reported previously by Torres-Orozco et al. (1996). In contrast with the LG fluvial zone, DO in the hypolimnion of the transitional and lacustrine zones stayed below $4 \mathrm{mg} \cdot \mathrm{O}_{2} \cdot \mathrm{L}^{-1}$. This is the minimum tolerable DO concentration for fish life in warm water according to USEPA (1986b). Low DO concentrations, which can inhibit aquatic 
life, were due to several factors, such as poor oxygen solubility at relatively high temperatures and altitude, stratification, and high nutrient concentrations generating high oxygen demanding microbial activity. This is in accordance with previous reports of high fish mortality and decreases in the number of migratory birds (Gutierrez-Díaz, 2006, Personal communication. Environmental Department Director, Cuautitlán Izcalli, Mexico).

\section{> MAJOR IONS AND NUTRIENTS}

Nitrate and nitrite were undetectable in LG throughout the experiment, but significant amounts of ammonium were measured. Average concentrations of ammonium were $5.0 \pm 2.5 \mathrm{mg} \cdot \mathrm{NH}_{4}^{+}-\mathrm{N} \cdot \mathrm{L}^{-1}$. This was probably linked to the anoxic conditions found in most of the LG water column, as the oxidation of ammonium to nitrate (nitrification) is oxygen dependent, thus nitrification in LG was probably inhibited. Additionally, nitrification can be sensitive to high concentrations of organic matter (Stüven et al., 1992). The absence of nitrifying activity was confirmed by ex situ tests during which ammonium was added to water samples and maintained for seven days under aeration, with no significant ammonia oxidation (data not shown). Furthermore, nitrate reduction to dinitrogen may have depleted nitrate and nitrite. Mateju et al. (1992) stated that denitrification becomes significant in tropical-subtropical water reservoirs at temperatures above $14^{\circ} \mathrm{C}$. Rapid denitrification under anaerobic conditions was observed during ex situ activity tests completed under anaerobic conditions with nitrate artificially added to water samples (Data not shown). In LG, the maximum DIN:SRP ratio was 7 , which is relatively low and suggests that the limiting nutrient for phytoplankton growth was nitrogen (Morris and Lewis Jr, 1988), as was observed previously in several tropical and subtropical lakes (Lewis Jr, 2002).

\section{$>$ CHLOROPHYLL A, SECCHI DEPTH, TROPHIC STATE AND WATER QUALITY INDEXES}

According to Carlson's trophic state index (TSI), LG remained hypereutrophic (average TSI value was $85.3 \pm 7.9$ ) throughout the monitoring period regardless of the seasonal variations or longitudinal zonation. In contrast, the maximum TSI value in LL was 48.2, which classifies it as mesotrophic. The mean WQI of LG was 24 , ranging from 18 in the fluvial zone to 28 in the lacustrine zone. According to Fernandez and Solano (2005), the WQI observed in LG suggests that the water in the reservoir is inappropriate for any use, including public supply, agriculture, fisheries, industry and recreation. By contrast, WQI of LL ranged from 63 to 70 , thus being of acceptable quality for all previously cited uses. Algal blooms occurred frequently over the stratification period and can be seen as an additional eutrophication indicator. The same observations were made at the Valle de Bravo reservoir (Merino-Ibarra et al., 2007), at Lake Lago de Chapala (Lind and Davalos-Lind, 2002), and at Lake Lago de Patzcuaro (Berlanga-Robles et al., 2002), all of which are located in sub-tropical areas of Mexico. This study confirms that cultural eutrophication is a major problem in several Mexican water reservoirs. Furthermore, the contrasting conditions of LG and LL, suggest that even though subtropical lakes are prone to eutrophication, urban wastewater discharges are the main factor accentuating this process.

\section{> MICROBIOLOGICAL QUALITY}

High concentrations of total coliform, faecal coliform and faecal streptococci were found in LG. Microbial indicators were consistently above the USEPA (1986a) single sample limit. Overall, $96 \%$ of total coliform counts exceeded the USEPA limit of 4 logCFU $100 \mathrm{~mL}^{-1}, 87 \%$ of the faecal coliforms counts exceeded the USEPA limit of $2.6 \log C F U 100 \mathrm{~mL}^{-1}$ and $77 \%$ of the faecal streptococci counts exceeded the USEPA limit of 1.5 logCFU $100 \mathrm{~mL}^{-1}$. These results 

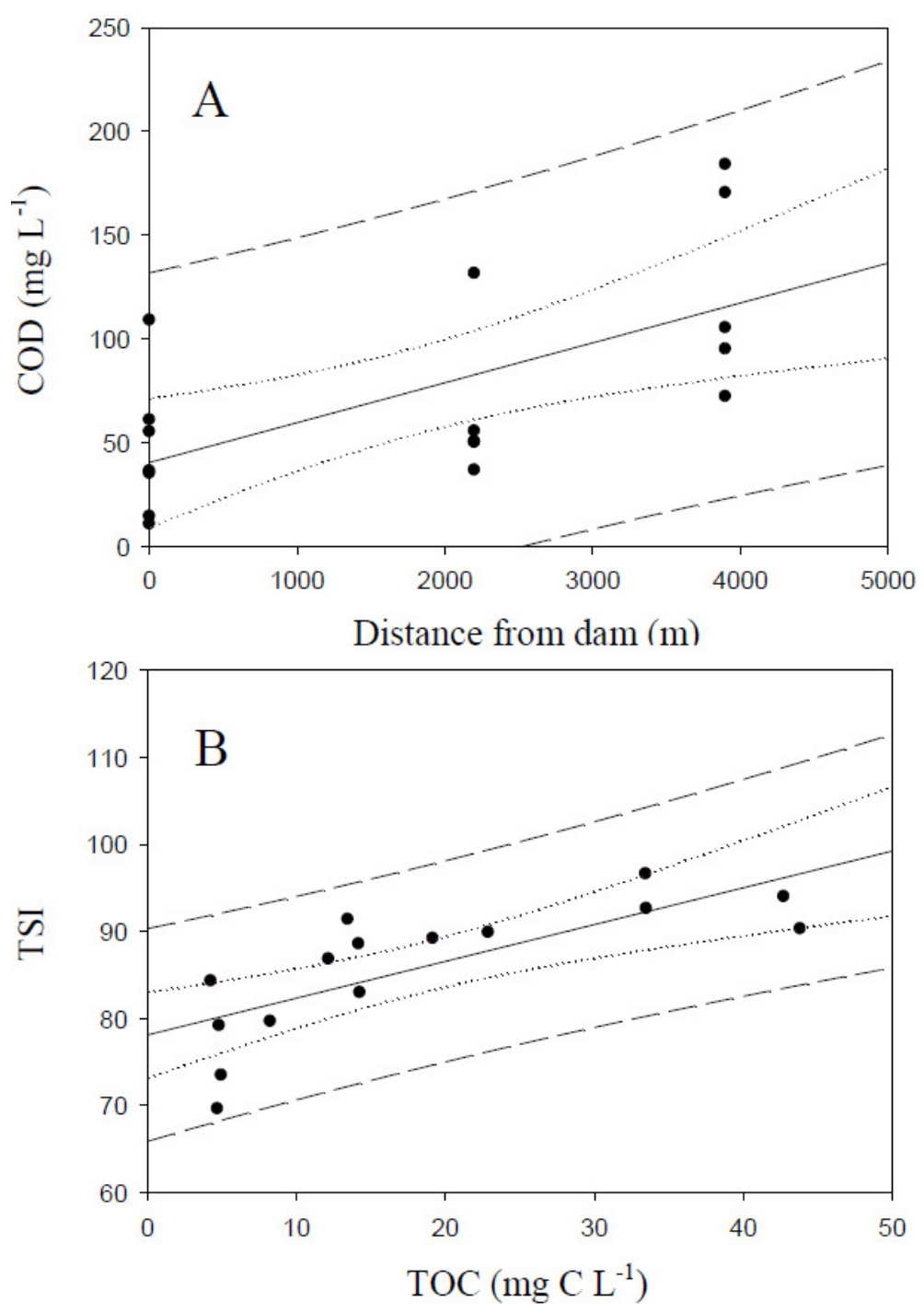

\section{Figure 6}

Pearson correlation analysis for COD vs Distance from the dam (A) for Trophic State Index vs. Total Organic Carbon (B). Linear model, solid line; 95\% confidence band, dotted line; 95\% prediction band, segmented line (see text).

are a strong indicator of wastewater discharges in LG. Moreover, the ratio of faecal coliforms to faecal streptococci (FC/FS), which is a clear indicator of the source of contamination, was greater than 4 in $77 \%$ of the samples. This clearly indicates that LG is contaminated with human faeces and represents a potential health risk (Dufour, 1997).

\section{> CORRELATION BETWEEN LONGITUDINAL ZONATION AND WATER QUALITY INDICATORS}

Several parameters presented a clear longitudinal zonation across the LG main axis (i.e. distance from the dam). Areas of increased distance from the dam (lacustrine zone) were found to be more polluted (fluvial zone). This zonation was confirmed by the Pearson product-moment correlation coefficients. Correlation with distance to the dam was significant for TOC $(r(26)=$ $0.51, P<0.01)$, COD $(r(17)=0.64, P<0.01)$, TN $(r(26)=0.37, P=0.05)$. For instance, Figure $6 \mathrm{~A}$ shows the confidence limits and prediction bands of the linear regression model for COD vs. distance to the dam. The parameters related to anthropogenic contamination were 
also correlated, i.e. TSI and TOC $(r(15)=0.76 P<0.001)$, TSI and TN $(r(15)=0.67, P=0.005)$ and TSI and Chlorophyl-a $(r(15)=0.54, P=0.05)$. Figure $6 \mathrm{~B}$ shows the confidence and prediction bands of the linear regression model for TSI vs. TOC. By comparison, there was no longitudinal zonation or significant correlation between the parameters in $L L(P>0.05)$. These contrasting results suggest that the longitudinal zonation observed in LG was a result of high anthropogenic organic inputs at the fluvial zone.

\section{> SEDIMENT ANALYSIS}

The sediments of the lacustrine zone in LG had higher TOC concentrations than of the fluvial zone. This is contradictory to our water quality observations, as water from the lacustrine zone contained significantly less contaminants than the fluvial zone (Figures 4 , 5). This suggests there is higher accumulation of organic matter in lacustrine zone sediments.

\section{>IMPACT OF WASTEWATER DISCHARGES AND POSSIBLE SOLUTIONS}

Several parameters unequivocally showed the impact of cultural pollution on LG. Table II showed important differences between LG and LL that can be attributed to sewage discharges. Nitrogen, phosphorus and carbon compounds in LG were at concentrations 3 to 40 times higher than in LL. Similarly, Chlorophyll-a, COD and $\mathrm{BOD}_{5}$ were significantly higher in LG than LL. As a result of this pollution, SDD was four times higher in LL than in LG, and an orthograde oxygen profile in LL contrasted with a clinograde profile and generalized anoxic conditions in LG.

The obvious long-term solution is to avoid pollution through an adequate wastewater treatment combined with the separation of pluvial and sewage discharges; both of them not applied yet. Effler et al. (2013) showed that with a reduction of pollutant input, the water quality of a lake can improve dramatically in a relatively short period. In addition, an immediate shortterm, but partial solution, may be artificial aeration. As previously shown, LG is subject to anoxic conditions in most part of the water column over time. Aeration would allow, at least partially, to compensate for the oxygen deficit and probably reduce the $\mathrm{BOD}_{5}$ concentration of the water. However, considering an energy consumption of approximately 1 to $1.5 \mathrm{~kW} \cdot \mathrm{h}$ per kg of oxygen transferred to the water, the energy cost would be important, but even small changes in oxygen inputs and mixing regimes may have an important positive impact on the lake's ecology (Heo et al., 2004). A third option could be to adapt a section of the fluvial zone of the reservoir to treat the wastewater influents in situ. This strategy has been reported by Martin et al. (2013) by using constructed wetlands and by Wu et al. (2006) with a plant-biofilm ditch.

\section{CONCLUSIONS}

LG may be classified as a warm monomictic water reservoir. Wastewater discharges in the fluvial zone have increased nutrient availability inducing hypereutrophication. The DIN:SRP ratio indicated that limited phytoplankton growth might be related to low nitrogen availability. As a result of eutrophication, oxygen deficiency was observed in the hypolimnion during most of the year. By contrast, algal blooms occasionally increased the epilimnion's DO concentrations above saturation. The high amount of bacterial pathogens represents a potential health risk not just for the surrounding population, but also for the population that consumes crops irrigated with its water. Furthermore, due to the anoxic conditions in the water column related to the LG hypereuthrophic state, massive fish die offs occur and consequently the number of migratory birds arriving each year has decreased. Thus, LG's deteriorated state transcends its regional impact as migratory birds are affected. Finally, most of the water quality indicators presented a clear longitudinal zonation in LG that was not observed in LL, suggesting that 
independent from the geographical location, the main cause for the deteriorated state of LG is the anthropogenic contamination related to an overall inadequate reservoir management.

\section{ACKNOWLEDGEMENTS}

This work was financially supported by the "Mexican National Council of Science and Technology" (CONACYT) and the Ministry of Environment and Natural Resources (SEMARNAT) through project grant No. 23661. J.H.-S. and A.S.-J. received grant-aided support from CONACYT (scholarship numbers 203591 and 203709, respectively). The authors are thankful to Karina Gutierrez and Alejandro Olvera from the Municipality of Cuautitlán Izcalli as well as to Roberto Espinoza, Cristina Aguilar and Miguel Buitrón (RIP) from Aquabiosphera for their technical assistance. The authors also thank Francisco Varona for his help with bathymetric data.

\section{REFERENCES}

APHA, 1999. Standard Methods for the Examination of Water and Wastewater. 20 edn. APHA, Washington, DC.

Berlanga-Robles C.A., Madrid-Vera J. and Ruiz-Luna A., 2002. Fish abundance and trophic structure from the commercial catch in Lake Patzcuaro, Mexico. Hydrobiologia, 467, 117-122.

Carlson R.E., 1977. A trophic state index for lakes. Limnol. Oceanogr., 22(2), 361-369.

Castro M.C., Rivera M., Crespo M., Martin-Garcia J.M. and Guerrero F., 2003. Morphological and sedimentological characterization of Honda temporary lake (souther Spain). Limnetica, 22, 147-154.

CONAGUA, 2007. Mexico's water statistics (in Spanish). CONAGUA, Mexico, D.F.

Cosgrove W.J. and Rijsberman F.R., 2000. World Water Vision: Making Water Everybody's Business. Earthscan Publications Ltd, London.

Dufour A.P., 1977. Escherichia coli: The fecal coliform. In: Hoadley AW, Dutka BJ (eds.), Bacterial Indicators/Health Hazards Associated with Water. ASTM Special Technical Publication, Philadelphia, 635, 48-58.

Effler S.W., O'Donnell S.M., Prestigiacomo A.R., Matthews D.A. and Auer, M.T., 2013. Retrospective Analyses of Inputs of Municipal Wastewater Effluent and Coupled Impacts on an Urban Lake. Water Environ. Res., 85, 13-26.

Fernandez N. and F. Solano, 2005. Indices de Calidad y de Contaminacion del Agua. Centro Publicaciones Universidad de Pamplona, Colombia.

Garcia E., 1973. Modifications to Köppen's system of climate classification (to suit the conditions of the Mexican Republic) (in Spanish). 2 edn. UNAM, Mexico.

Hakanson L., 1981. A Manual of Lake Morphometry. Springer-Verlag, Berlin.

Heo W.M. and Kim B., 2004. The effect of artificial destratification on phytoplankton in a reservoir. Hydrobiologia, 524, 229-239.

Hutchinson E.G., 1957. Geography, Physics and Chemistry. A Treatise on Limnology. Wiley, New York, 1. Hutchinson E.G. and Loffler H., 1956. The thermal classification of lakes. P. Nat. Acad. Sci., 42, 84-86.

INEGI, 2011. Census of Population and Housing: Socio-demographic Panorama Mexico (in Spanish), Mexico, D.F.

Lewis Jr W.M., 1983. A revised classification of lakes based on mixing. Can. J. Fish. Aquat. Sci., 40 1779-1787.

Lewis Jr W.M., 1987. Tropical Limnology. Annu. Rev. Ecol. Syst., 18, 159-184.

Lewis Jr W.M., 1996. Tropical lakes : How latitude makes a difference. In: Boland FSaKT (ed.), Perspectives in tropical limnology. SPB Academic Publishing Amsterdam.

Lewis Jr W.M., 2002. Causes for the high frequency of nitrogen limitation in tropical lakes. Verh. Internat. Verein. Limnol., 28, 210-213.

Lind O.T. and Davalos-Lind L.O., 2002. Interaction of water quantity with water quality: the Lake Chapala example. Hydrobiologia, 467, 159-167. 
Lindstrom M. and Hakanson L., 1999. An empirical model for prediction of lake water suspended particulate matter. Ecol. Model., 121, 185-198.

Martin M., Oliver N., Hernandez-Crespo C., Gargallo S. and Regidor M.C., 2013. The use of free water surface constructed wetland to treat the eutrophicated waters of lake L'Albufera de Valencia (Spain). Ecol Eng., 50, 52-61.

Mateju V., Cizinska S., Krejci J. and Janoch T., 1992. Biological water denitrification: A review. Enzyme Microb. Tech., 14, 170-183.

Merino-Ibarra M., Monroy-Rios E., Vilaclara G., Castillo F.S., Gallegos M.E. and Ramirez-Zierold J., 2007. Physical and chemical limnology of a wind-swept tropical highland reservoir. Aquat. Ecol., 42, 335-345.

Morris D.P. and Lewis Jr W.M., 1988. Phytoplankton nutrient limitation in Colorado mountain lakes. Freshwater Biol., 20 315-327.

Stüven R., Vollmer M. and Bock E., 1992. The impact of organic matter on nitric oxide formation by Nitrosomonas europaea. Arch. Microbiol., 158, 439-443.

Thornton K.W., Kimmel B.L. and Payne F.E., 1990. Reservoir Limnology: Ecological Perspectives. John Wiley \& Sons, New York.

Torres-Orozco B.R.E., Jimenez-Sierra C. and Perez-Rojas A., 1996. Some limnological features of three lakes from Mexican neotropics. Hydrobiologia, 341, 91-99.

Tundisi J.G., 1994. Tropical South America: Present and perspectives. In: Margalef R Limnology Now: A Paradigm of Planetary Problems. Elsevier Science, Amsterdam, 353-424.

USEPA, 1986a. Ambient water quality criteria for bacteria. EPA440/5-84-002. Washington, DC.

USEPA, 1986b. Quality Criteria for Water: EPA 440/5-86-001. Office of Water Regulations and Standards, Washington, DC.

Vazquez G., Favila M.E., Madrigal R., Montes del Olmo C., Baltanas A. and Bravo M.A., 2004. Limnology of crater lakes in Los Tuxtlas, Mexico. Hydrobiologia, 523, 59-70.

Waltz A., Hughes A., Bonnet P. and Basson G., 2007. Dams and the World's Water. International Commision On Large Dams, Paris.

Welch E.B., and Jacobi J.M., 2004. Pollutant effects in freshwater: applied limnology. Spon Press, London.

Wetzel R.G., 2001. Limnology: Lake and River Ecosystems. 3 edn., Elsevier Academic Press, San Diego.

Wetzel R.G. and Likens G.E., 2000. Limnological Analysis. 3 edn. Springer-Verlag, New York.

Wu Q.T., Gao T., Zeng S.C. and Chua H., 2006. Plant-biofilm oxidation ditch for in situ treatment of polluted waters. Ecol. Eng., 28, 124-130.

Zhang C., 2007. Fundamentals of Environmental Sampling and Analysis. Wiley-Interscience, New York. 